\title{
What are the ideas and motivations of bureaucrats within a religiously contested society?
}

O'Connor, K. (2017). What are the ideas and motivations of bureaucrats within a religiously contested society? International Review of Administrative Sciences, 83(1), 1-22. https://doi.org/10.1177/0020852315574996

Link to publication record in Ulster University Research Portal

\section{Published in:}

International Review of Administrative Sciences

Publication Status:

Published (in print/issue): 01/03/2017

DOI:

$10.1177 / 0020852315574996$

\section{Document Version}

Author Accepted version

\section{General rights}

Copyright for the publications made accessible via Ulster University's Research Portal is retained by the author(s) and / or other copyright owners and it is a condition of accessing these publications that users recognise and abide by the legal requirements associated with these rights.

\section{Take down policy}

The Research Portal is Ulster University's institutional repository that provides access to Ulster's research outputs. Every effort has been made to ensure that content in the Research Portal does not infringe any person's rights, or applicable UK laws. If you discover content in the Research Portal that you believe breaches copyright or violates any law, please contact pure-support@ulster.ac.uk. 
What are the ideas and motivations of bureaucrats within a religiously contested society? International Review of Administrative Sciences - forthcoming

Dr Karl O’Connor

Institute for Research in the Social Science,

School of Criminology, Politics and Social Policy,

The University of Ulster, Northern Ireland

\begin{abstract}
This article reports research on bureaucrat behaviour. Where discretion exists, do primary associations such as religious, gender or racial identity guide behaviour or are these associations superseded by secondary learned professional or technocratic attachments? Using the theoretical lens of representative bureaucracy and $Q$ methodology to investigate bureaucrat role perceptions, two distinct bureaucrat typologies are identified in Belfast. The evidence demonstrates that an elite level bureaucrat may actively represent his or her own professional interests or alternatively, may seek out and actively represent the interests of the political elite as a collective. The findings have implications for representative bureaucracy research as it is demonstrated that an elite level bureaucrat may actively represent something other than a primary identity. This contribution also provides a useful insight into everyday life within a bureau of a successful power-sharing system of governance.
\end{abstract}

Keywords: representative bureaucracy; conflict management; public administration; elite level bureaucrat; Belfast

\title{
Points for Practitioners
}

Politicians and bureaucrats from Northern Ireland are perpetually being invited to 'teach the lessons' of their power-sharing experience. This article highlights the importance of the elite level bureaucrat in sustaining power-sharing regimes and provides an empirical basis for those seeking to draw on the Northern Ireland experience of conflict management and post conflict governance. 


\section{Introduction}

As acknowledged by Stanfield (1996: 15), we know 'virtually nothing' about how ethnically differing peoples manage to coexist peacefully. Wake-Carroll and Carroll (2000:120) reiterate Stanfield's assertion reminding us that 'we need to know a great deal more about the ways in which diverse ethnic communities are sometimes able to coexist in relative harmony'. Further, in one of the seminal contributions to conflict management literature of the previous decade, Varshney (2002:6) reinforces this belief, maintaining that 'until we study ethnic peace, we will not be able to have a good theory of ethnic conflict'. With the intention of expanding scholarly understanding of ethnic peace, this research draws on public administration theory to help us understand the role of the elite level bureaucrat in sustaining power-sharing mechanisms of conflict management.

A multitude of studies contribute to our understanding of how conflict management institutions should be designed. These institutions usually emerge from either powersharing or power-dividing schools of thought. However less is known about how bureaucrats operate within these institutional designs. Accepting that the traditional Wilsonian politics public administration dichotomy does not exist, elite level bureaucrats must surely influence the success of conflict management regimes. This case study examines their role perceptions, focusing particularly on their representation perceptions within the powersharing society. When a decision is being taken, who or what do elite level bureaucrats represent? As it is accepted that identification guides behaviour in instances of bureaucrat discretion, we need to understand if secondary learned attachments can supersede the primary identities of elite level bureaucrats. Hindera (1993) defines two types of association: primary associations as those into which we are born such as gender, race, ethnicity etc, while secondary associations on the other hand are those which we generate, or socially 
construct - attachment to an organisation or football club for example. The lens of representative bureaucracy is used to determine these representation perceptions.

\section{Introduction to the case study}

Until 1997, Belfast returned a majority unionist Council, which was found to represent only one community and even at that, Bollens (2000: 230) finds the interests of this community to have been poorly served with local politicians being more interested in the Anglo-Irish agreement than in the everyday lives of their constituents. In 1997, the electoral results left non-aligned Alliance holding the balance of power. The politicians were forced to cooperate in order for the Council to continue to function. Since 1997, power-sharing, relying on informal norms and practices, has governed the functioning of the City Council.

Bollens' (2000) pre power-sharing research, conducted in 1994, suggests that policy making in Belfast was neutral or colourless'. Bureaucrats, he finds, employed technical rational criteria in the allocation of resources, distancing themselves from the issues of ethnic identity, power inequalities and political exclusion. While bureaucrats were involved in conflict management, they were planning for two cities, two communities and were not involved in the conflict management-conflict resolution process. This neutral strategy relies on technical rational data in resource allocation, distancing itself from issues of ethnic identity, power inequalities and political exclusion. As citizens are treated as individuals and not as being from a particular community, this gives rise to the term colour-blind. However, despite being ignored in government plans and blueprints, sectarianism was nonetheless acknowledged in policy formulation - 'it was as if we were carrying out a plan for two cities that happened to overlap each other'; what Bollens terms 'plural planning' (Bollens, 2000: 233). While addressing the two colours of the city, blue and green, no effort was made to 
'disturb the volatile territoriality of the city' (ibid: 233). Before power-sharing, sectarianism was 'accepted as a characteristic of the urban setting' (ibid: 233). The bureaucratic elite did not perceive it to be their role to challenge this status quo. The changing nature of the wider public administration in Northern Ireland is analysed from devolution to direct rule by Birrell (1978) and direct rule back to devolution by Carmichael and Osborne (2003) while Knox and Carmichael, $(2005,2006)$ investigate reform efforts within the Northern Ireland civil service. The reason for situating the study within Belfast is presented in the next section.

The next part of this article draws on existing representative bureaucracy scholarship identifying the two opposing schools of thought which suggest that a bureaucrat may actively represent his or her primary or secondary identity. The following paragraphs provide a rationale for investigating the possibility of a professional association emerging. This is followed by the methods section, together with a short note on the importance of role perceptions in determining policy proposals. The findings are then introduced before returning to the central hypothesis.

\section{Representative bureaucracy}

Kingsley's (1944) representative bureaucracy put forward that it did not matter whether a politician or elite level bureaucrat made a decision, as within the British civil service, both parties shared similar beliefs, experiences and values. As such, a decision by a bureaucrat would mirror that of the politician, given paralleled access to information. The theory was not uncontentious at the time as bureaucrats were supposed to dispose, not propose. The essence of Kingsley's argument was that the public administration would always represent the interests of its composite class - the middle class. The theory was significantly advanced by Van Riper (1958:552) where he supposed that decisions made by the bureaucracy 
mirrored the preferences, 'ethos and attitudes' of the society which they governed. Mosher (1968: 12) further developed the theory, differentiating between "that which the bureaucracy is" and "that which the bureaucracy does". According to Mosher, passive representativeness concerns the origin of individuals and the degree to which, collectively, they mirror society, while in active representation an individual is expected to press for the interests of those he or she represents (Hindera, 1993: 417). Hannah Pitkin (1967) describes this as the difference between that which the bureaucrat 'is' (passive) and that which the bureaucrat 'does' (active). In other words, passive representation would simply concern itself with the number of Turkmen, Kurds and Arabs within the Kirkuk bureaucracy relative to the population of the city. Active representation on the other hand concerns itself with the actions of each group within the bureaucracy, attempting to determine if or when representation within the administration equates with the flow of benefits to that particular group.

Some studies have shown that blacks and women portray evidence of active representation as minorities within a bureaucracy - i.e. that women would support the interests of women within the bureaucracy and members of the black community similarly advocate the interests of the wider black population (Mansbridge, 1999; Keiser et al, 2002; Meier and Nicholson-Crotty, 2006). By extension, within a contested society one would expect that, in the case of Belfast, Catholics would represent Catholic interests and Protestants would represent Protestant interests. However another body of research finds incorporating qualified professionals into a bureaucracy also incorporates their professional values into the bureaucracy (March and Olsen, 1995). Organisations depersonalise relationships which allows for a technocratic mentality to develop (Ferguson, 1984; Radaelli and O'Connor, 2009). This incorporation of professional values into the bureaucracy will 
lead the bureaucracy to develop its own set of values and norms which, through socialisation, could potentially supersede traditional norms. Rehfuss (1986: 459) not only found that role and representation perceptions of women and minorities differed little from their white male counterparts within the administration, but that they appeared to share a 'management ideology'. Thus instead of Catholics representing Catholic interests and Protestants representing Protestant interests, we would expect to find both Catholic and Protestant bureaucratic elites to represent common professional, technocratic interests; likewise for the republicans, nationalists, loyalists and unionistsii. Meier and O'Toole (2006) and Keiser et al (2002) ascertain that a critical mass is required for the formulation of an actively representative bureaucracy. Thus a department would require numerical sufficiency of a particular ethnicity (or set of values) for benefits to begin to flow to that ethnicity, (or to those in society holding those values). Put succinctly by Keiser et al (2002: 557):

"If professionals who see advocacy for a particular group as their role dominate a bureaucracy, we should expect bureaucratic outputs to be distributed to benefit that group."

Therefore, the argument goes, if Catholics are numerically sufficient within the Belfast bureaucracy, benefits should correspondingly flow to that group. While Meier and Nicholson-Crotty (2006) are able to show that an increase in female police officers corresponds with an increase in instances of rape actually reported to the police, is this because female police officers take forward the cases of female victims, or as Lim (2006) would suggest, because female norms and values have been adopted by those males working closely with their female counterparts, thereby changing the norms of the organisation? If the latter is the case, through socialisation with women men can now represent the interests of women, the norms of the bureaucracy are now more representative of those in society at large. As indicated by Rehfuss (1986) above, one 
therefore does not have to 'passively represent' to 'actively represent'. Kennedy (2008) strengthens this argument referring to those providing services to the mentally and physically disabled. Within an ethno-politically divided city, do the bureaucratic elite possess these secondary, learned/socially constructed associations or do they attach themselves to a primary, ethnic, personal identity? As Reissman (1949: 305) puts forward, the formal structure, interpersonal relationships and the surrounding social milieu all contribute to the 'social role the bureaucrat fills'. A further study which assists in generating expectations within the contested society is that of Grissom et al (2009) where they found 'situation' to matter. They found blacks in Southern American states to be more likely to actively represent blacks in society than blacks in Northern American states. This would lead us to expect that in ethno-politically contested environments, or societies new to power-sharing forms of governance, bureaucrats would be more likely to maintain a primary identity. The emerging power-sharing society is therefore a most useful case selection as it is most conducive to proving the hypothesis wrong (ie. that a secondary learned attachment cannot supersede a primary attachment). Further, everyday life remains divided in Belfast where two thirds of Belfast's population continue to live in areas where over $81 \%$ of residents are of the same religion (Shirlow and Murtagh, 2006). Belfast therefore is an example of what Eckstein (1975: 118) would have called a crucial case of the most likely case variety: if passive representation on behalf of a religious identity is likely to translate into active representation on behalf of a religious identity, it is most likely to do so in Belfast.

\section{Why a professional attachment?}

Active representation most definitely exists within all bureaucracies; however before international organisations consider administrative reform strategies, it is necessary to 
understand precisely what values bureaucratic elites actively represent. In an attempt to avert bureaucrats from representing their primary ethno-national identities, Mengistu and Vogel (2006) submit that a national Ethiopian identity could potentially supersede primary tribal identities. In a country such as Ethiopia, where over eighty different ethnicities inhabit the state, obtaining a critical mass of each tribal group so that benefits would flow to each group would be impractical. A national Ethiopian identity, they submit, would supersede tribal identities, thereby ensuring that ethnic groups are not simply representing their tribal positions within the bureaucracy. However, in ethnically contested societies, different ethnicities or communities attribute different importance to the concept of state nationality. In some cases the legitimacy of the state is even contested. Unlike nation states where identification with the nation and the state usually exist simultaneously as a primary identity, identification with the governing state within the contested society is often in a secondary, or learned, capacity. Since the traditionally disadvantaged ethnic communities are not prone to the acceptance of state authority, such allegiances would be difficult to form as they would be in direct contrast to their primary 'national' (ethnic/community/tribal) identities. Emerging from these studies of representative bureaucracy this paper tests the following hypothesis: A secondary attachment can supersede a primary attachment among elite level bureaucrats within an emerging powersharing society.

\section{A note on role perceptions and methods}

Failure to account for bureaucrat norms and values can lead to the failure of administrative reform which in turn influences the success of power-sharing regimes (O'Connor, 2012). In Lebanon, a significant proportion of responsibility for the failure of bureaucratic reform is 
placed on the failure of The Office of the Minister of State for Administrative Reform (OMSAR) to work with the existing indigenous public administration, as opposed to working against it (El-Zein and Sims, 2004). Despite the good intentions of OMSAR, its disregard for the existing individual bureaucratic norms and values, contributed to the projects failure. Without an understanding of bureaucrat role perceptions, norms and values any structural change will be manipulated by the unknown human condition, generating unintended consequences. Exploring how the bureaucratic elite behave within power-sharing societies can inform our expectations of bureaucratic behaviour and hence demonstrate how structural change will be exploited by one of the most influential actors within the governance process. Do bureaucrats within a power-sharing environment actually represent their personal community backgrounds or have they, through education, time, socialisation or other explanatory variables developed a professional attachment which supersedes their ethnic identities? Following Selden et al's (1999) study, bureaucrats could (theoretically) be entirely responsive to the political level akin to Wilsonian doctrines of public administration. Alternatively, bureaucrats could possess neutrality Weberian-style values. These neutrality attributes differ markedly from those responsive to the political level - bureaucrats with neutrality values give prominence to legislation and treaties, not the political policies of the minister, they maintain a neutral position on potentially divisive decisions and find that they represent the integrity of the organisation as opposed to serving the minister. Together with these role interpretations it is also important to understand bureaucrat's perceptions of equity and efficiency and their position on the traditional right/left divide (Selden et al, 1999).

The image of an 'internally coherent self' has been widely rejected and replaced by a conception of individuals as 'collections of roles and identities that may even be loosely 
coupled' (Egeberg, 1999: 458). 'The crucial question is: Which role or identity becomes evoked in a particular decision situation? Roles, identities and situations can all be ambiguous' (March 1994: 61, Egeberg, 1999: 459). This paves the way for the generation of bureaucrat typologies or as Stephenson (1935) would have termed them: clusters of subjectivity. The role perceptions of the bureaucrat have been deemed to be of importance in determining the policy-making processes (Selden et al, 1999; Brewer et al 2000; O'Connor, 2014). It is acknowledged that bureaucrats within the contested society possess multiple attachments and may simultaneously possess a multitude of identities that may sometimes even directly conflict with each other. A methodology that allows for a multitude of preferences to be simultaneously explored is therefore required. $Q$ methodology is particularly adept at measuring competing preferences simultaneously. For a concise and very readable introduction to Q see Van Exel and De Graff (2005) or Brown (1980).

The concourse for this research originated from a review of the bureaucrat behaviour literature. Focusing on concepts such as legitimacy, representation, role perception, identity, scope of governance and motivation, statements representing each of the theoretically existent characteristics underlined above were identified ${ }^{\mathrm{iii}}$. These in turn were whittled down to 46 statements in much the same way as would be done when preparing a questionnaire.

As in $Q$ who the interviewees are is more important than the quantity of interviews; a list was compiled of all directors, all heads of department and some managers, in what were identified as areas 'key' to conflict management (areas incorporating a potentially contentious aspect and also areas where the Council had the primary responsibility for service provision). Of these forty-seven, twenty-five were chosen for interview. Twenty of these agreed to partake in the study (a response rate of $80 \%$ ). To reiterate, interviews were 
targeted on the basis of position within the public administration - not perceived nationality, gender, race or creed. As it transpired, eight Catholics, seven Protestants, and five indicating neither background were interviewed. However, given that we are looking at a contested city, it is important to establish the representativeness of the sample. Therefore the religious backgrounds of all forty seven top decision makers within Belfast City Council were obtained. Where $\mathrm{N}=47$ (entire bureaucratic elite), the ratio of Catholics to Protestants is $1: 1.14$. In this $\mathrm{N}=20$ sample the ratio of Catholics to Protestants is $1: 1.04$. Thus in terms of religion, our sample is as representative of the target population as can be expected.

\section{The Findings}

In this $Q$ study, interviewees were required to sort opinion statements in a quasi-normal distribution ranging from +3 to -3 . The interviewee $Q$-sorts (responses) were entered into the software: $P Q$ method (Schmolck), subject to Principal Component Analysis where the emerging matrix was then rotated using Varimax criteria, revealing two similar bureaucrat factors or typologies. Each typology represents a conceptual template originating from where each respondent categorised the statements. Factors or typologies are simply interviewees who were found to share similar beliefs about a given subject. The diversity of the two typologies is represented in table one below. Table two explains how each respondent contributes to the definition/make-up of each of the typologies (or how they come into being), while table three then identifies the characteristics of each of our two factors.

Insert tables 1, 2 and 3 about here 
Each typology is presented below in turn. Throughout the findings section, reference is made to various statements presented in table three (statement number is indicated in brackets), together with evidence from the interviews (Interviewee number is identified as 'Interview X'). While both typologies share many views, let us first consider what differentiates them.

\section{Factor One: Policy makers and advocators}

This first typology has a good working relationship with the political actors within the city. While those weighing on this factor do not substitute their own political values with those of the political elite (42), they perceive their actions to be legitimate as the political level agree with their decisions and recommendations $(22,26)$. This factor however does not believe that resources should be allocated according to the wishes of the political level regardless of their opinions (7). Their role is not simply to advise the Minister (10) but to actively pursue positions that they perceive are the interests of the entire urban public (11). When differences do emerge, they maintain their expert beliefs for as long as politically possible (40). While they do attribute importance to the neutrality of the bureaucracy, (28) neutrality is interpreted to mean that all urban citizens are represented by the administration. This factor does not follow the rules of the administration under all circumstances (8). They are not overtly technocratic, accounting for political factors when making decisions (19). Administrators should not be neutral, but prioritise good management and social equity (17). They take the initiative in proposing policies, mobilising support for them and question policies that may run counter to the general interest of the urban population (36). The views of think tanks and international organisations such as the OECD and EU are held in high regard by this factor (41). They actively advocate in favour of policy positions that they 
perceive represent the needs of the entire urban public (11), and actively advocate in favour of policy positions that address the needs of minority citizens (3). Conflict management is a function for this factor - where differences exist, they see it as their role to mediate and determine a course of action that satisfies everyone (14).

This factor is not overly attached to a particular policy area (44), but instead represents a broader vision for the city. Equity commitments trump policy specific commitments among those weighing on this factor $(1,31)$, particularly as they operate within a contested city (6). Equity between ethnic groups however should not be a determinant in resource allocation - just because one community is given a resource, this should not be a reason to give the other community the resource (20). This factor also possesses a concurrent commitment to efficiency $(21,2)$.

The legitimacy of their actions is derived from their responsibility to attain an equitable, fair and prosperous society - not the law, political direction, or their expert beliefs. As indicated by the positioning of statements $38,33,18,32$, this factor believes in the public provision of state services and are open and committed to public sector reform. This factor disagrees most strongly with the idea of representing one's community (primary identity) within the bureaucracy $(24,30,35,39,43,45,46)$. A further noteworthy finding is the irrelevance the factor attributes to recruitment statements $(2,15)$. This factor embodies many of the characteristics put forward by Waldo (1971) and Groeneveld and Van de Walle (2010). They could be categorised as 'Image IV' of Aberback et al's (1981) theoretical view of the relationship between politicians and bureaucrats in that responsibility for formulating policy, brokering interests and articulating interests is shared by politicians and bureaucrats. The following quotations from the follow-on discussions give a further insight into the motivations, norms and values of this factor: 
'It is only when we bring things to the attention of the political level that they have influence' (Interview 1)

'There is an incapacity at the political level to deal with the more technical stuff' (Interview 2)

'I only present an options paper when cuts are to be political' (Interview 4)

'My area is quite technical...the political level rubber stamp my decisions' (Interview 5)

'I view my role as a coordinator...I put things in a framework in which they can agree' (Interview 9)

'My role is to steer them [political level] in the right way' (Interview 12)

'I have a broader view for the city, as opposed to a political view' (Interview 15)

'My role is to manage the decision-making process' (Interview 17)

'You have to do your homework before Council meetings...I build a relationship with Councillors so they may have confidence in me' (Interview 19)

Those aligning themselves along this factor come from both communities in Northern Ireland. Three were from the Protestant community, while five had a Catholic community background. Three identified with neither community. Two felt British, four Irish and five Northern Irish. Five respondents had a degree and six held a Masters or higher qualification. Four were fairly attached to their religion; four were not attached, while a further three described themselves as not at all attached.

\section{Factor Two: Policy designers and implementers}

Those aligning with factor two see themselves as representing government and see their role as to carry out the wishes of the urban government. Overall they are a more technocratic factor and are inclined to retreat to the evidence in order to persuade the political level to cooperate. Unlike factor one, when there is a conflict of interest between their personal, expert beliefs and those of the political level, they are more inclined to follow those of the political level (25). They are also the most likely factor to suppress their own values in favour of those of the political level (42). Similar to factor one however, they are rarely pressurised by elected officials to alter their expert recommendations or decisions 
(26). They see their role as to carry out the wishes of urban government $(5,12)$. While this factor is highly responsive to the political level, they do not simply provide advice to the political level (10). They aim for government that works better and costs less (21). They are against private sector provision of state services $(8,18)$, but are also less enthusiastic about public sector reform (38) and less concerned with directly representing the interests of citizens than factor one (33). They are also attached to professional norms and values (11, $36,40)$, however this factor possess simultaneous attachments to the political level.

While factor one actively pursue broader societal objectives, factor two are more technocratic. They attribute significant importance to their policy area (44). They tend to prioritise the goal of efficiency, providing technically feasible and efficient solutions to the political level (27). This is not to mean that they allocate resources according to technical criteria only (4). Political factors also need to be considered when taking decisions and making recommendations (19). While they disagree with affirmative action $(2,15)$, this factor are aware of the contested nature of the environment in which they work and like factor one involve themselves in conflict management, mediating between political differences (14). Unlike factor one, factor two believe that as they operate within a contested city, resources should balance technical and demographic criteria (20). Efficiency is not always a priority (1). In terms of equity, they do not disproportionately represent minority groups (3). Neutrality is highly regarded by this factor (28). Unlike factor one, neutrality is seen more traditionally, being grounded in the law (13) and technocracy (2). Together with factor one, factor two possess a strong commitment to public service. They are however more rule bound; viewing public service in a supporting capacity to the political level. Factor two similarly rejects any possibility of actively representing their personal communities; their primary concern being to develop an efficient administration so as to be 
responsive to the wishes of the urban government $(2,21,12,5,25)$. However, while they are responsive to the political level, they also expect the political level to be responsive to them $(7,9,40)$.

Factor two, while incorporating a commitment to professional ideas, are found to agree with a greater number of 'political responsive' and 'neutrality' statements. While not an exact fit, they are therefore closer to Aberback et al's (1981) 'Image III' of the relationship between the political and bureaucratic level - while they are active in implementing and formulating policy, they do try to seek out the ideas of the political level. Whilst taking into account the equity concerns of a contested city, this factor's values lean more towards efficiency concerns. In sum, this factor is less likely to actively represent broader societal goals, and is more interested in actively developing a more efficient administration to carry out the wishes of the urban government. They are however significant stakeholders in the policy design process and significantly influence the outcome of public policy. Similar to factor one they can be described as 'co-producers', however they are more likely to seek out and represent the policy goals of the political level rather than seeking to represent what they perceive to be broader societal goals. The following quotes from the informal interview support these findings:

'I meet with the political level to determine what their priorities are or knowing where they are at...I need to know what tactic to deploy' (Interview 20)

'When Councillors disagree I retreat to the evidence' (Interview 18)

'Generally I like to give a recommendation to Councillors, if there are a number of options I will discuss it with individual Councillors beforehand' (Interview 16)

'I keep the debate technical' (Interview 14)

'Our role is to inform, not to take decisions' (Interview 7)

'My role is to make sure they take a fully informed decision. ...the primary value of the administration is neutrality' (Interview 8)

'There is always a technical basis for decisions' (Interview 14) 
Four Protestants, two Catholics and two identifying with neither community weighed significantly on this factor. Four possessed a British identity, one an Irish identity and three possessed a Northern Irish identity. One held a degree while seven had a Master's degree or higher. Again four were fairly attached to their religion, while four described themselves as 'not at all attached'. As with factor one, typology alignment does not correlate with primary identity.

\section{Returning to the hypothesis}

As identified in table one, both Belfast factors share many beliefs and perceptions. Factor one however are motivated by their own personal goals and objectives, grounded in their technocratic expertise or broader social objectives. Factor two, while still actively involved in the policy-making process, try and ascertain and implement the goals of the political elite. While two distinguishable typologies do emerge, a number of core governance beliefs were held by all respondents. We see that both factors agree with the principle that equity is more important than efficiency $(1,6)$, however as outlined above, there is a difference in how equity is interpreted. Both factors have a strong commitment to good governance (21). They are not willing to follow the rules of the bureaucracy under all circumstances $(8,37)$; nor do they perceive their role as simply to provide input with their expertise or to provide advice (10). Both factors see themselves as co-producers within the policy process, providing technically feasible and efficient solutions (27). Both factors also involve themselves in conflict management decisions, and consider it their function to mediate between differing political viewpoints (14). Neutrality and impartiality are of paramount importance (27), but both factors differ on how these concepts are interpreted (17). The findings therefore demonstrate that a secondary learned attachment can supersede a primary identity within a contested society. In summary, while both factors are equally 
active in the management of conflict, factor two are more likely to ascertain and pursue the goals of the political elite as a collective, while factor one are more likely to pursue what they themselves perceive to be the wishes of society.

\section{Concluding remarks}

The article has explored the attitudes and role perceptions dominating the politicoadministrative axis for 'without knowledge of the values held by the bureaucracy, it is futile to attempt any full determination of the degree of political control' (Meier and O'Toole, 2006:29). It is this politico-administrative axis that most concerns the investigation into how conflict is regulated. As power-sharing emerges, the political-administration dichotomy is the primary determinant in the policy-making process. The typologies give an insight into this dynamic process.

The research has uncovered a number of important findings. First and foremost active representation on behalf of a secondary attachment can emerge within a contested society governed by power-sharing. Drawing on Meier and O'Toole's (2006) research it is accepted that values affect behaviour. Akin to Meier and O'Toole (2006:93), the article finds that certain groups within the 'bureaucracy [are] acting consistently with [their] own values rather than being directed by electoral institutions'. However, contrary to findings by Bradbury and Kellough (2007) and Wilkins (2006) their own values are not necessarily their primary identities. While indeed our factors are found to be involved in active representation, this active representation is based on a secondary learned attachment. Keiser's (1999:87) study of street-level bureaucrats found that 'professional norms play a large role in directing the ways that street-level bureaucrats use their discretion'. Similarly, at the elite level, active representation is found to exist on behalf of a secondary learned 
attachment. Callahan and Olshfski (2006) found that in the absence of a strong state narrative, latent (personal) narratives come to the fore and in turn guide behaviour. By its design, $\mathrm{Q}$ method categorises the competing preferences of bureaucrats. Representing a personal community is not even demonstrated as a latent narrative among our sample. While $Q$ methodology measures the range of views on a topic, not the extent to which they are ascribed, the findings demonstrate that it is possible for elite level bureaucrats to be motivated by secondary learned attachments. The findings cannot tell us however the extent to which these factors are ascribed to among the bureaucratic elite. Survey research based on these results would be able to answer such a question. Further, the article does not examine the extent to which epistemic communities have emerged in Belfast. While many bureaucrats perceive themselves as 'experts' in their policy areas, there is no evidence to suggest that this expertise causes them to share an identity. Indeed, institutional or other environmental reasons could influence bureaucrat preferences.

While previous studies have identified that the bureaucratic elite play a significant role in regulating conflict management mechanisms ( $0^{\prime}$ Connor, 2012), this study has demonstrated the range of narratives that guide the bureaucrat in Belfast in his or her everyday life within the bureau. Thus it can be said that active representation definitely exists within the emerging power-sharing society but that which is actively represented varies between bureaucrats. It is also clear that bureaucrats weighing on similar factors do not possess similar nationalities. While it has been suggested in the literature that a common 'national' identity could supersede these tribal affiliations, it is suggested that in an environment where demand is high and resources are limited, instances where both the national and the ethnic identity could collide would be frequent. Following Meier and O'Toole (2006) and Keiser et al (2002), under such circumstances, the bureaucrat would 
then be expected to revert to his/her primary tribal identity. It is put forward that attachments along professional lines should be more sustainable than those built along the dubious notion of nationality. While a mutual national and tribal identity would be difficult, attachment to regulatory reform principles or to improving social cohesion or to poverty alleviation should not directly conflict with a primary ethno-national attachment. This study has demonstrated that it is not unrealistic to expect such attachments, even in the environment where they are least likely.

\section{End of manuscript}

This research has been kindly supported by the Economic and Social Research Council (ESRC) of the UK as part of the ESRC large grant scheme: Conflict in Cities and the Contested State: Everyday life and the possibilities for transformation in Belfast, Jerusalem and other divided cities, UK Economic and Social Research Council Large Grants Scheme, [RES-060-25-0015, 2007-2012]. An earlier version of this paper was presented to the Public Administration Specialist Group of the Political Studies Association, UK. I am also indebted to Professor Brian Smith and the two anonymous reviewers for their most helpful comments on an earlier draft of this article. The usual disclaimer applies. 
Figures and Tables

Table 1: Correlation of the Factors

\begin{tabular}{|l|l|l|}
\hline & F1 & F2 \\
\hline 1 & 1.0000 & 0.7236 \\
\hline 2 & 0.7236 & 1.0000 \\
\hline
\end{tabular}


Table 2: The relationship between Belfast interviewees and factors

This table describes how closely each interviewee $(p)$ weighs on each factor For example; interviewee no. 2 is .69 in factor 1 and .29 in factor 2 . The $X$ denotes that the respondent's answers contributed to the make-up of that particular factors general perception.

\begin{tabular}{|ccc|}
\hline$P$ & 1 & 2 \\
\hline 1 & $0.4410 X$ & 0.3984 \\
\hline 2 & $0.6900 X$ & 0.2930 \\
\hline 3 & 0.3180 & $0.5756 X$ \\
\hline 4 & $0.8255 X$ & 0.2930 \\
\hline 5 & $0.6809 X$ & 0.3334 \\
\hline 6 & $0.7835 X$ & 0.2523 \\
\hline 7 & 0.4800 & $0.5878 X$ \\
\hline 8 & 0.4110 & $0.7521 X$ \\
\hline 9 & $0.6292 X$ & 0.4703 \\
\hline 10 & 0.1563 & $0.7290 X$ \\
\hline 12 & $0.6994 X$ & 0.2474 \\
\hline 13 & $0.6736 X$ & 0.4321 \\
\hline 14 & 0.5054 & $0.5914 X$ \\
\hline 15 & $0.7865 X$ & 0.1306 \\
\hline 16 & 0.4047 & $0.5140 X$ \\
\hline 17 & $0.5679 X$ & 0.4553 \\
\hline 18 & 0.4586 & $0.6509 X$ \\
\hline 19 & $0.7391 X$ & 0.3806 \\
\hline 20 & 0.0951 & $0.8344 X$ \\
\hline
\end{tabular}




\section{Table 3: Factor Arrays}

In the table below, the relationship between each factor (or group of individuals) and each statement is identified. In other words, the table identifies where each collective of individuals placed the $Q$ statements. (eg. statement one would have been placed in the -1 , mildly disagree, category by interviewees in factors 1 and 2)

\begin{tabular}{|c|c|c|c|c|}
\hline & & Factor Arrays & & $\begin{array}{l}\text { fast } \\
\text { tor } \\
\text { nber }\end{array}$ \\
\hline No. & Classification & Statement & F1 & \\
\hline 1 & Efficiency & $\begin{array}{l}\text { If a government employee is forced to choose } \\
\text { between the most efficient policy and the most } \\
\text { equitable policy, the most efficient alternative } \\
\text { should be chosen }\end{array}$ & -1 & -1 \\
\hline 2 & Efficiency & $\begin{array}{l}\text { Bureaucracies should be staffed by professionally } \\
\text { trained, technically competent individuals. The } \\
\text { most qualified person should always get the job }\end{array}$ & 0 & 2 \\
\hline 3 & Equity & $\begin{array}{l}\text { I recommend or actively advocate in favour of } \\
\text { policy positions that address the needs and } \\
\text { concerns of minority citizens }\end{array}$ & 1 & -1 \\
\hline 4 & Efficiency & $\begin{array}{l}\text { I advocate the allocation of resources according to } \\
\text { technical criteria only - those who need the } \\
\text { service should get it }\end{array}$ & 0 & -1 \\
\hline 5 & Political & $\begin{array}{l}\text { My role is to carry out the wishes of urban } \\
\text { government }\end{array}$ & 1 & 3 \\
\hline 6 & Equity & $\begin{array}{l}\text { Given the cultural diversity within my city, equity } \\
\text { and fairness between various ethnicities is more } \\
\text { important than efficiency }\end{array}$ & 1 & 0 \\
\hline 7 & Political & $\begin{array}{l}\text { Resources should be allocated according to the } \\
\text { wishes of the political elite, regardless of my } \\
\text { opinions }\end{array}$ & -1 & 0 \\
\hline 8 & Neutral & $\begin{array}{l}\text { My role is to follow the rules of the bureaucracy at } \\
\text { all times no matter what the circumstances }\end{array}$ & -2 & -1 \\
\hline 9 & Political & $\begin{array}{l}\text { I value the views of the urban political elite, and } \\
\text { those positively influence my personal opinions }\end{array}$ & 0 & -1 \\
\hline 10 & Political & $\begin{array}{l}\text { My role is to serve as an expert within my policy } \\
\text { area, serving ONLY to provide advice to my } \\
\text { Minister/Council Committee }\end{array}$ & -1 & -1 \\
\hline 11 & Professional & $\begin{array}{l}\text { I recommend or actively advocate in favour of } \\
\text { policy positions that I perceive represent the } \\
\text { needs and interests of the entire urban public }\end{array}$ & 3 & 2 \\
\hline 12 & Political & $\begin{array}{l}\text { In my daily work I represent the elected } \\
\text { government of the city }\end{array}$ & 1 & 3 \\
\hline 13 & Neutral & $\begin{array}{l}\text { My decisions are legitimate as I follow procedures } \\
\text { established by law and/or secondary legislation }\end{array}$ & 0 & 3 \\
\hline
\end{tabular}




\begin{tabular}{|c|c|c|c|c|}
\hline 14 & Professional & $\begin{array}{l}\text { My role is to mediate conflicting interests and find } \\
\text { a course of action that satisfies everyone. }\end{array}$ & & 2 \\
\hline 15 & Equity & $\begin{array}{l}\text { Given the cultural diversity of my city, a } \\
\text { prerequisite for good governance would be } \\
\text { recruitment from all sectors of the community, } \\
\text { even if this means that the best person does not } \\
\text { always get the job. On the job training can correct } \\
\text { this imbalance. }\end{array}$ & 0 & -2 \\
\hline 16 & Personal & $\begin{array}{l}\text { I actively encourage procedures that give my } \\
\text { community the greater access to the public } \\
\text { services that the deserve }\end{array}$ & -2 & -3 \\
\hline 17 & Professional & $\begin{array}{l}\text { Administrators are not neutral. They should be } \\
\text { committed to good management and social equity } \\
\text { as values }\end{array}$ & 3 & 0 \\
\hline 18 & $\begin{array}{l}\text { Pro-state } \\
\text { facilitation } \\
\text { of services }\end{array}$ & $\begin{array}{l}\text { I believe that by putting the interests of business } \\
\text { first, benefits will flow to citizens }\end{array}$ & -1 & -2 \\
\hline 19 & Neutral & $\begin{array}{l}\text { In contemporary social and economic affairs it is } \\
\text { essential that technical considerations be given } \\
\text { more weight than political factors }\end{array}$ & -1 & -1 \\
\hline 20 & Equity & $\begin{array}{l}\text { Given that I operate within a contested city, } \\
\text { resource allocation should balance technical } \\
\text { criteria (those who need it get it) and demographic } \\
\text { criteria (if one community gets a resource, the } \\
\text { other should get it too - regardless of necessity) }\end{array}$ & -1 & 1 \\
\hline 21 & Efficiency & $\begin{array}{l}\text { Public employees should aim for governance that } \\
\text { works better and costs less }\end{array}$ & 3 & 2 \\
\hline 22 & Political & $\begin{array}{l}\text { My decisions are legitimate as I only follow the } \\
\text { decisions of the political level }\end{array}$ & 1 & 0 \\
\hline 23 & Neutral & $\begin{array}{l}\text { In my daily work I represent my department and } \\
\text { the wider civil service }\end{array}$ & 1 & 1 \\
\hline 24 & Personal & $\begin{array}{l}\text { In my daily work I value the views of community } \\
\text { interest groups with whom I share a personal } \\
\text { political affinity }\end{array}$ & -2 & -2 \\
\hline 25 & Political & $\begin{array}{l}\text { When a conflict of interests arises between the } \\
\text { wishes of the urban government and my own } \\
\text { technical beliefs or the wishes of the political } \\
\text { leaders of my personal community, I automatically } \\
\text { and unquestionably follow the wishes of the } \\
\text { government }\end{array}$ & 0 & 2 \\
\hline 26 & Professional & $\begin{array}{l}\text { Elected officials rarely pressurise me to alter my } \\
\text { personal expert decisions }\end{array}$ & 1 & 1 \\
\hline 27 & Efficiency & $\begin{array}{l}\text { I see my role as to devise solutions that are } \\
\text { technically feasible and efficient }\end{array}$ & 1 & 2 \\
\hline 28 & Neutrality & $\begin{array}{l}\text { I believe that neutrality and impartiality should be } \\
\text { the primary values within a bureaucracy }\end{array}$ & 2 & 3 \\
\hline 29 & Neutrality & My decisions are legitimate on the basis of my & 0 & 0 \\
\hline
\end{tabular}




\begin{tabular}{|c|c|c|c|c|}
\hline & & $\begin{array}{l}\text { technical expertise and by the fact that I provide } \\
\text { technically feasible solutions }\end{array}$ & & \\
\hline 30 & Personal & $\begin{array}{l}\text { My role is to achieve the goals of the elected } \\
\text { political representatives of my own community }\end{array}$ & -3 & \\
\hline 31 & Equity & $\begin{array}{l}\text { As I am involved in the policy making process, I } \\
\text { ought to do so in a manner that advances the } \\
\text { interests of those less well off in society, } \\
\text { regardless of their background }\end{array}$ & 3 & 1 \\
\hline 32 & $\begin{array}{l}\text { Pro-state } \\
\text { facilitation } \\
\text { of services }\end{array}$ & $\begin{array}{l}\text { The best way to ensure efficient public service to } \\
\text { the entire urban community is to facilitate the } \\
\text { private sector in service provision }\end{array}$ & -1 & -2 \\
\hline 33 & $\begin{array}{l}\text { Pro-state } \\
\text { provision of } \\
\text { services }\end{array}$ & $\begin{array}{l}\text { I believe that citizens needs are best advanced } \\
\text { through directly putting their needs first }\end{array}$ & 1 & 0 \\
\hline 34 & Neutral & $\begin{array}{l}\text { I am reluctant to assume a leadership role in } \\
\text { divisive policy issues. This is the prerogative of } \\
\text { elected officials }\end{array}$ & 0 & 0 \\
\hline 35 & Personal & $\begin{array}{l}\text { My decisions are legitimate as I represent the } \\
\text { interests of my community }\end{array}$ & -3 & -3 \\
\hline 36 & Professional & $\begin{array}{l}\text { I take the initiative in proposing policies, } \\
\text { mobilising support for them, and questioning } \\
\text { policies that may run counter to the general public } \\
\text { interest }\end{array}$ & 2 & 1 \\
\hline 37 & Neutral & $\begin{array}{l}\text { I know what is legal, not what is right. I stick to } \\
\text { what is legal }\end{array}$ & 0 & 0 \\
\hline 38 & $\begin{array}{l}\text { Pro-state } \\
\text { provision of } \\
\text { services }\end{array}$ & $\begin{array}{l}\text { The best way to ensure efficient public service to } \\
\text { the entire urban population is through public } \\
\text { sector reform so that services may be provided } \\
\text { equitably and efficiently by the public sector }\end{array}$ & 2 & 0 \\
\hline 39 & Personal & $\begin{array}{l}\text { Given the recent history of the city, I can of course } \\
\text { empathise with the needs of my community - My } \\
\text { loyalty is to them and I work for their interests } \\
\text { within the legal constraints of the bureaucracy }\end{array}$ & -3 & -2 \\
\hline 40 & Professional & $\begin{array}{l}\text { When a conflict of interest arises between the } \\
\text { wishes of the political level and my personal } \\
\text { expert beliefs, I pursue my expert beliefs for as } \\
\text { long as politically possible }\end{array}$ & 2 & 1 \\
\hline 41 & Professional & $\begin{array}{l}\text { In my daily work I value the views of international } \\
\text { and specialised organisations such as the IMF, } \\
\text { World Bank, EU, OECD, policy specific think tanks } \\
\text { and NGOs. }\end{array}$ & 2 & 0 \\
\hline 42 & Political & $\begin{array}{l}\text { In my work I try to substitute my own political } \\
\text { values with those of the political elite }\end{array}$ & -2 & 1 \\
\hline 43 & Personal & $\begin{array}{l}\text { My community pay taxes; it is my duty to } \\
\text { represent them within the bureaucracy. Other } \\
\text { bureaucrats advocate the allocation of resources } \\
\text { for their communities, it is my duty to provide }\end{array}$ & -3 & -3 \\
\hline
\end{tabular}




\begin{tabular}{|l|l|l|lc|}
\hline 44 & Professional & $\begin{array}{l}\text { resources for my community } \\
\text { area, then to my department }\end{array}$ & 1 \\
\hline 45 & Personal & $\begin{array}{l}\text { Although it is rarely necessary, when needs be I do } \\
\text { stand up for the rights and interests of my } \\
\text { personal community }\end{array}$ & -2 & -2 \\
\hline 46 & Personal & $\begin{array}{l}\text { I find it easier to relate to Councillors/Ministers } \\
\text { from my own personal community. It is only logical } \\
\text { - we share a common background }\end{array}$ & -2 & -1 \\
\hline
\end{tabular}




\section{References}

Aberbach, J.D, Putnam, R.D. and Rockman, B.A. (1981) Bureaucrats and Politicians in Western Democracies, Cambridge, Mass.: Harvard University Press

Birrell, D. (1978) 'The Northern Ireland Civil Service-from Devolution to Direct Rule', Public Administration, 56(3): 305-319

Bollens, S. (2000) On Narrow Ground: Urban Policy and Conflict in Jerusalem and Belfast. (Albany, NY. State University of New York Press)

Bradbury, M.D. and Kellough, J.E. (2007) 'Representative Bureaucracy: Exploring the Potential for Active Representation in Local Government', Journal of public Administration Research and Theory Vol.18 No.4 pp697-714

Brown, S.R. (1980) Political subjectivity: Applications of Q methodology in political science, (Yale University Press)

Callahan, K. and Olshfski, D. (2006) 'War Narratives: Framing Our Understanding of the War on Terror', Public Administration Review, 66 (4): 554-568

Carmichael, P. (2002) 'The Northern Ireland Civil Service Characteristics and Trends since 1970', Public Administration, 80(1): 23-49

Carmichael, P. and Osborne, R. (2003) 'The Northern Ireland civil service under direct rule and devolution' International Review of Administrative Sciences, 69(2): 205-217

Eckstein, H. (1975). Case studies and theory in political science. In F. I. Greenstein \& N. W. Polsby (Eds.), Handbook of political science. Political science: Scope and theory Vol. 7, pp. 94137. Reading, MA: Addison-Wesley.

Egeberg, M. (1999) 'Transcending intergovernmenatlism? Identity and role perceptions of national officials in EU decision-making', Journal of European Public Policy, 6(3): 456-74

El-Zein, F. and Sims H. (2004) 'Reforming war's administrative rubble in Lebanon', Public Administration and Development, Vol.24 pp279-288

Ferguson, K. (1984) The Feminist Case Against Bureaucracy, Philadelphia: Temple University Press

Grissom, J.A., Nicholson-Crotty, J. and Nicholson-Crotty, S. (2009) 'Race, Region and Representative Bureaucracy', Public Administration Review, Vol.69 pp911-919

Groeneveld, S., \& Van de Walle, S. (2010). A contingency approach to representative bureaucracy: Power, equal opportunities and diversity. International Review of Administrative Sciences, 76, 239-258. 
Hindera, J. (1993) 'Representative Bureaucracy: Further Evidence of Active Representation in the EEOC District Offices', Journal of Public Administration Research and Theory, Vol.3 pp415-429

Keiser, L.R., (1999) 'State Bureaucratic Discretion and the Administration of Social Welfare Programs: The Case of Social Security Disability', Journal of Public Administration Research and Theory Vol. 9. No.1 pp87-106

Keiser, L.R., Wilkins VM, Meier KJ, Holland CA. (2002) 'Lipstick and Logarithms: Gender, Institutional Context and Representative Bureaucracy', American Political Science Review, Vol.96 pp543-564

Kennedy, B. (2008) 'Putting Representative Bureaucracy into Context: A Qualitative Analysis of Role Perception', Paper presented at the annual meeting of the APSA 2008 Annual Meeting, Hynes Convention Centre, Boston, Massachusetts

Kingsley, D.J. (1944) Representative Bureaucracy, Yellow Springs, OH: Antioch Press

Knox, C. and Carmichael, P. (2005) 'Improving Public Services: Public Administration Reform in Northern Ireland', Journal of Social Policy, 35(1): 97-120

Knox, C. and Carmichael, P. (2006) 'Bureau shuffling? The Review of Public Administration in Northern Ireland', Public Administration, 84 (4) 941-965

Lim, H. (2006) 'Representative Bureaucracy: Rethinking Substantive Effects and Active Representation', Public Administration Review, Vol.66 pp193-204

Mansbridge, J. (1999) 'Should Blacks Represent Blacks and Women Represent Women? A Contingent "Yes"', Journal of Politics, Vol. 61 No.3 p628

March, J.G. (1994). A Primer on Decision Making. How Decisions Happen. New York, NY: The Free Press.

March, J.G. and Olsen, J.P. (1995) Democratic Governance, New York: The Free Press

Meier, K. J., O'Toole, L. J. (2006) Bureaucracy in a democratic state: A governance perspective, Baltimore: The Johns Hopkins University Press

Meier, K.J. and Nicholson-Crotty, J. (2006) 'Gender, Representative Bureaucracy and Law Enforcement: The Case of Sexual Assault', Public Administration Review, Vol.66 pp850-860

Mengistu, B and Vogel, E. (2006) 'Bureaucratic Neutrality Among Competing Bureaucratic Values in an Ethnic Federalism', Public Administration Review, 66 pp205-216

Mosher, F.C. (1968) Democracy and the Public Service, 1st Edition, New York : Oxford University Press 
O'Connor, K. (2012) Belfast Revisited: Everyday policy-making in a contested environment, Irish Political Studies Vol.27 No.3

O'Connor, K. (2014) Public Administration in Contested Societies, Basingstoke: Palgrave Macmillan

Pitkin, H.F. (1967) The Concept of Representation, Berkeley: University of California Press

Radaelli, C.M. and O'Connor, K. (2009) 'How bureaucratic elites imagine Europe: a convergence of governance beliefs?', Journal of European Public Policy, Vol.16 No.7 pp971989

Rehfuss, J.A. (1986) 'A representative bureaucracy? Women and minority executives in California career service', Public Administration Review, Vol.46 pp454-460

Reissman, L. (1949) 'A study of role conceptions in bureaucracy', Social Forces, Vol.27. No.3 pp305-310

Schmolck, P. PQ METHOD Software (freeware) : University of the Federal Armed Forces Munich, Department of Education [online] http://www.Irz.de/ schmolck/amethod/

Selden, S.C., Brewer, G.A. and Brundy, J.L. (1999) 'Reconciling competing values in public administration: Understanding the administrative role concept', Administration and Society, Vol.31 pp171-204.

Shirlow, P. and Murtagh, B. (2006) Belfast: Segregation, violence and the city, (London: Pluto)

Stanfield, J. H. (1996) 'Multi-ethnic Societies and Regions', The American Behaviour Scientist, 40 (September): 8-17

Stephenson, W. (1935) Correlating persons instead of tests', Character and Personality, Vol.4 No.17-24

Van Exel, N.J.A. and G. de Graff (2005) Q Methodology, A sneak preview [online] Download from www.jobvanexel.nl]

Van Riper, P.P. (1958) History of the United States Civil Service, New York: Harper and Row Varshney, A. (2002) Civic Life and Ethnic Conflict: Hindus and Muslims in India, (New Haven: Yale University Press) 
Waldo, D. (1971). Public administration in a time of turbulence. Scranton, Chandler Pub. Co

Wake-Carroll and Carroll (2000) Accommodating ethnic diversity in a modernizing democratic state: theory and practice in the case of Mauritius Ethnic and Racial Studies Volume 23, Issue 1, Pp120-1421

Wilkins, V. (2006) 'Exploring the Causal Story: Gender, Active Representation, and Bureaucratic Priorities', Journal of Public Administration Research and Theory Vol.17No.1 pp. 77-94

Karl O'Connor is Lecturer in Public Policy and Management within the Institute for Research in the Social Sciences at the University of Ulster, Northern Ireland. His research interests include public administration, conflict management, development and mixed methods. He has published in West European Politics, Journal of European Public Policy, Irish Political Studies, and has recently had a monograph - Public Administration in Contested Societies published by Palgrave. 


\footnotetext{
'The fieldwork for Bollens' research was conducted shortly after the first IRA ceasefire in 1994 which ultimately paved the way for the Good Friday Agreement in 1998. Power-sharing has been the mode of governance within Belfast City Council since 1997. In 2007 the Council adopted a 'committee' governance structure.

ii In Radaelli and O'Connor (2009) European Council committee members were found not to adopt a common European identity but a common technocratic attachment - they shared an attachment to their professional associations be these attachments to the regulatory reform agenda or direct corporate taxation. Bureaucrats need not share opinions on the subject. Where they disagree, this disagreement is based on their own expertise, not national preferences.

iii Of course some statements contain elements of two of these theoretically defined characteristics. Classifications are of course subjective. While the classification of the statement may be disputed, as statements are interpreted with reference to the position of all other statements, classification does not have a significant effect on findings.
} 